University of Wollongong

Research Online

Faculty of Engineering and Information

Faculty of Engineering and Information

Sciences - Papers: Part B

Sciences

2019

Behaviour and strength of bolted connections failing in shear

Matthew Elliott

University of Wollongong, mde813@uowmail.edu.au

Lip H. Teh

University of Wollongong, Iteh@uow.edu.au

Aziz Ahmed

University of Wollongong, aziza@uow.edu.au

Follow this and additional works at: https://ro.uow.edu.au/eispapers1

Part of the Engineering Commons, and the Science and Technology Studies Commons

Research Online is the open access institutional repository for the University of Wollongong. For further information contact the UOW Library: research-pubs@uow.edu.au 


\title{
Behaviour and strength of bolted connections failing in shear
}

\begin{abstract}
This paper investigates the behaviour and strength of structural steel bolted connections whose failure modes involve shear yielding and/or fracture. Such failure modes include the shear-out (or tearout) and the block shear failure modes. The use of shear failure planes corresponding to the bolt diameter is shown to result in significant overestimations of the ultimate capacities for bolted connections with reduced or no hole clearance. In contrast, the use of the effective (or active) shear planes are consistently accurate for the specimens with standard, oversize or no clearance bolt holes. The paper points out that the location of fracture initiation can be easily misidentified by a superficial inspection of the deformed and fractured state of the bolt hole. The paper also explains that the ultimate shear-out capacity of a steel bolted connection can be reached without fracture due to geometric changes downstream of the bolt, provided the reduction in resistance is not offset by strain hardening. The explanation is demonstrated through a finite element analysis that does not simulate fracture, but is able to accurately determine the ultimate shear-out capacity of a high-strength steel specimen tested by independent researchers.

\section{Disciplines}

Engineering | Science and Technology Studies

Publication Details

Elliott, M. D., Teh, L. H. \& Ahmed, A. (2019). Behaviour and strength of bolted connections failing in shear. Journal of Constructional Steel Research, 153 320-329.
\end{abstract}




\section{Behaviour and Strength of Bolted Connections Failing in Shear}

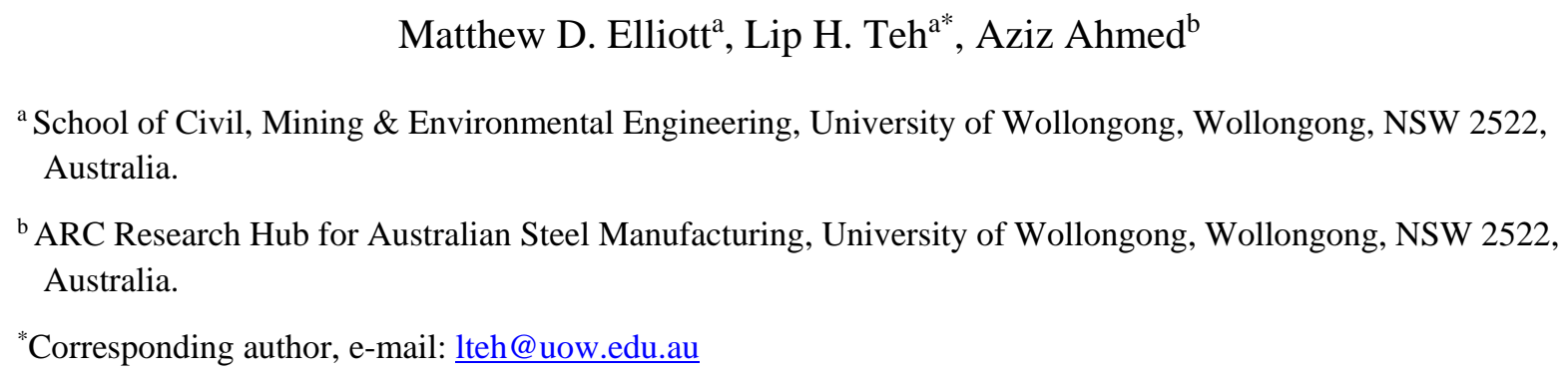

Abstract: This paper investigates the behaviour and strength of structural steel bolted connections whose failure modes involve shear yielding and/or fracture. Such failure modes include the shear-out (or tearout) and the block shear failure modes. The use of shear failure planes corresponding to the bolt diameter is shown to result in significant overestimations of the ultimate capacities for bolted connections with reduced or no hole clearance. In contrast, the use of the effective (or active) shear planes are consistently accurate for the specimens with standard, oversize or no clearance bolt holes. The paper points out that the location of fracture initiation can be easily misidentified by a superficial inspection of the deformed and fractured state of the bolt hole. The paper also explains that the ultimate shear-out capacity of a steel bolted connection can be reached without fracture due to geometric changes downstream of the bolt, provided the reduction in resistance is not offset by strain hardening. The explanation is demonstrated through a finite element analysis that does not simulate fracture, but is able to accurately determine the ultimate shear-out capacity of a high-strength steel specimen tested by independent researchers.

Author keywords: bolted connection, block shear, connection design, gusset plate, shear failure, shear-out 


\section{Introduction}

The ability of various strength models proposed in the literature to accurately determine the ultimate shear-out capacity of a bolted connection has been shown by Teh \& Uz [1] to depend on the assumed shear failure planes. A post-fracture state following a shear-out failure is illustrated in Figure 1(a). Through verifications against seven independent experimental programs from around the world [2-8], Teh \& Uz [1] have demonstrated that only the model assuming the shear failure plane that lies between the net and the gross shear planes is consistently accurate. This finding was reinforced by Teh \& Deierlein [9] through verifications against the experimental programs of Moze \& Beg [10-11].

The finding regarding the shear failure plane for determining the shear-out capacity is consistent with that for the block shear capacity [9, 12]. A post-fracture state following a block shear failure is illustrated in Figure 1(b). Teh \& Deierlein [9] verified their block shear strength model against twelve independent experimental programs [5, 7, 11, 13-21], while Zeynali et al. [12] used their own test results. While there is a minor difference in the assumed shear coefficient, the finding of the two studies are the same, i.e. in a block shear failure the shear failure plane lies between the net and the gross shear planes.

Interestingly, it has recently come to the authors' attention that Kamtekar [22] defined a shear failure plane(s) depicted in Figure 2 , which corresponds to the bolt diameter rather than the bolt hole diameter. Kamtekar [22] stated that the use of such planes resulted in estimates that were more accurate than those provided by Eurocode 3 [23]. While the shear-out estimates of Eurocode 3 [23] has been known to be very conservative [24], the alternative shear failure plane [22] is worthy of a detailed investigation.

In this paper, the shear failure plane defined by Kamtekar [22] is compared against the effective shear plane defined by Teh \& Deierlein [9] through verifications against independent laboratory test results of bolted connection specimens failing in shear-out or block shear. Most of the specimens have small or standard hole clearances, but some of them have hole clearances that are larger than that defined by the specification [25] to be oversize. It may be noted that the effective shear plane [9] is the same as the active shear plane for shear-out $[1,24]$. 
The verifications against laboratory test results are complemented by verifications against validated finite element analysis results of bolted connections without hole clearance. The inclusion of such bolted connections is insightful since in this case Kamtekar's shear plane coincides with the gross shear plane.

Finite element analysis is also used to identify the location of fracture initiation in a bolted connection undergoing shear-out failure, and to investigate whether fracture is a necessary condition for reaching the ultimate shear-out capacity.

\section{Proposed shear failure planes}

The ultimate shear-out (also termed "tearout") capacity $P_{\text {so }}$ of a structural steel bolted connection is specified in Equation (J3-6d) of the AISC Specification for Structural Steel Buildings [25]

$$
P_{\mathrm{so}}=0.75 A_{n v} F_{u}=1.5 L_{n v} t F_{u}
$$

in which $L_{\mathrm{nv}}$ is considered to be the "net shear length", defined for a single-bolt connection in Figure 3(a). The variable $t$ is the plate thickness, and $F_{u}$ is the material tensile strength.

The AISC code equation has been shown to result in significant errors on either side of conservatism [1, 24]. For connections with short shear planes, the use of the net shear length $L_{\mathrm{nv}}$ results in underestimations of the ultimate shear-out capacity. On the other hand, the use of an exaggerated shear coefficient of 0.75 results in overestimations of same for connections with long shear planes.

The use of the shear coefficient equal to 0.75 in the current specification [25] appears to be intended to compensate for the replacement of the gross shear length $L_{\mathrm{gv}}$ used in the earlier specification [26]

$$
P_{\mathrm{so}}=0.5 A_{g v} F_{u}=L_{g v} t F_{u}
$$

The gross shear length $L \mathrm{gv}$ is defined in Figure 3(b) for a single-bolt connection. Despite the assumption of a reduced shear coefficient equal to 0.5 , the use of the gross shear length $L \mathrm{gv}$ has been shown to result in overestimations of the ultimate shear-out capacity for many connections tested in the literature, especially those with more than one row of bolts [1]. 
82 Teh \& Uz [1] proposed the following equation for determining the ultimate shear-out capacity of a structural steel bolted connection, which uses the well-established shear coefficient of 0.6

$$
P_{\mathrm{so}}=0.6 A_{e v} F_{u}=1.2 L_{e v} t F_{u}
$$

in which $A_{\text {ev }}$ is the mean between the net and the gross shear areas, illustrated for a singlebolt connection in Figure 3(c). The variable $A_{\mathrm{ev}}$ is called the effective shear area in the present work, consistent with the terminology of Teh \& Deierlein [9].

Through comparisons against various strength models that use the net and the gross shear planes, it was concluded that the use of the effective shear length $L_{\mathrm{ev}}[1,9]$ in conjunction with the well-established shear coefficient of 0.6 results in the most consistently accurate estimates of the ultimate shear-out capacity of specimens tested in the literature [2-8, 10-11].

However, Kamtekar [22] had earlier contended that the shear failure plane(s) of a bolted connection undergoing shear-out or block shear failure corresponds to the bolt diameter, as illustrated in Figure 2 . The proposed shear-out equation is similar in form to Equation (3), but the assumed shear length is different in principle

$$
P_{\mathrm{so}}=0.6 A_{k} F_{u}=1.2 L_{k} t F_{u}
$$

The variable $L_{\mathrm{k}}$ is defined by Kamtekar [22] in Figure 2 .

Kamtekar [22] also proposed the following equation for determining the block shear capacity $P_{\text {bs }}$ based on the same treatment of the shear failure plane(s)

$$
P_{\mathrm{bs}}=A_{n t} F_{u}+0.6 A_{k} F_{u}
$$

The variable $A_{n t}$ is the area of the net tension plane in a block shear failure mode. The generic block shear failure planes are depicted in Figure 4. The variable $A_{\mathrm{k}}$ denotes Kamtekar's shear planes, while the variable $A_{\mathrm{ev}}$ in the figure corresponds to the effective shear length $L_{\mathrm{ev}}$ [9]. It can be seen from Figures 2 and 3(c) that, depending on the hole clearance, Kamtekar's shear area may be numerically similar to the effective shear area.

The block shear equation proposed by Teh \& Deierlein [9] is 


\section{Comparisons against laboratory test results}

110 Since the net and the gross shear planes have been shown to be unreliable failure planes [1, 9], only the effective shear plane [9] and Kamtekar's shear plane [22] will be compared against each other in this paper. In the following tables, the variable $P_{\mathrm{t}}$ denotes the ultimate loads obtained in the laboratory tests. The ratio $P_{\mathrm{t}} / P_{\mathrm{bs}}\left(\right.$ or $P_{\mathrm{t}} / P_{\mathrm{so}}$ ) is termed the professional factor in the reliability analysis literature. A professional factor greater than unity indicates that the strength model is conservative, and a value less than unity indicates an overestimation of the actual strength. An empty cell in the tables indicates that the value in the above cell applies.

Table 1 compares Equations (5) and (6) for the block shear specimens tested by Aalberg \& Larsen [13]. The hole clearance of all specimens was $1 \mathrm{~mm}$. The variable $n_{\mathrm{r}}$ in the table denotes the number of bolt rows. The specimens are the same as those analysed by Teh \& Deierlein [9], but the computed professional factors for Equation (6) are slightly different due to the round-off of the bolt spacing from $47.5 \mathrm{~mm}$ to $48 \mathrm{~mm}$ in the earlier work, which obtained the data from a second-hand source [16].

Table 1 shows that the use of the effective shear plane in Equation (6) resulted in more accurate estimates of the block shear capacities. Due to the use of Kamtekar's shear plane, Equation (5) resulted in overestimations greater than $10 \%$ for some block shear specimens tested by Aalberg \& Larsen [13].

However, it can be seen from Figure 2 that, for a bolted connection with a standard hole clearance, Kamtekar's shear plane [22] may be close to the effective shear plane [9]. Puthli \& Fleischer [5] tested bolted connections with a hole clearance of $3 \mathrm{~mm}$ for a $27 \mathrm{~mm}$ diameter bolt, which complies with Table J3.3M of the specification [25] for a standard hole. Each specimen in Table 2 had a row of two bolts and failed in shear-out (which was called "bearing” by Puthli \& Fleischer [5]). Table 2 shows that the difference between Equations (3) and (4), which use the effective shear plane and Kamtekar's shear plane, respectively, for the shear-out specimens with a standard hole clearance is less than $5 \%$. 


\section{Comparisons for no hole clearance connections}

As indicated previously, the specimens in Table 1 had a hole clearance of $1 \mathrm{~mm}$. It will be interesting to establish the implications of using Equations (5) and (6) for bolted connections with no hole clearance, in which case Kamtekar's shear plane [22] is the gross shear plane. For this purpose, the finite element models developed by Elliott \& Teh [27] were first validated against the laboratory test results in Table 1.

The hexahedral reduced integration brick element C3D8R available in ABAQUS 6.12 Standard [28] was used to model the gusset plates, while the 3D analytical rigid body revolved shell was used to model the bolts. The bolts were displaced together to simulate loading of the gusset plates as the displacements would be resisted by the surface contacts between the bolts and the bolt holes at the downstream end, in the same manner as conducted by Clements \& Teh [29].

However, unlike the work of Clements \& Teh [29], fracture was simulated in the present finite element analysis [27], although it was not necessary for determining the block shear limit load (but was required to trace the complete load-deflection graphs that included the post-fracture path). Element deletion was activated when the target degradation was reached at an integration point. The equivalent plastic displacement at failure was set to be 0.2 . Interested readers should consult reference [27] for the methodologies of deriving the true stress-strain curve and the damage initiation parameters, which are given in Figure 5 and Table 3, respectively. The plasticity of the steel material was handled through the von Mises yield criterion and the Prandtl-Reuss flow rule with isotropic hardening. The elastic modulus was assumed to be $200 \mathrm{GPa}$, and the Poisson's ratio was 0.3 .

For the block shear specimens tested by Aalberg \& Larsen [13], only half of each gusset plate was modelled to take advantage of symmetry. The mirror images of the symmetric-half models were later added in plotting the shear stress contours to facilitate illustration.

It can be seen from the last column of Table 1 that the finite element models were able to closely replicate the ultimate test loads. Figure 6 compares the experimental and the FEA load-displacement graphs for Specimens T-8 and T-11 [13].

The validated finite element models were then modified so that the bolt diameter was the same as the hole diameter, i.e. $19 \mathrm{~mm}$. The ultimate limit loads $P_{u}$ obtained by the finite 
element analysis are given in Table 4. It can be seen that Equation (5) results in significant overestimations of the ultimate loads of all models, in contrast to Equation (6). While the effective shear plane used in the latter equation remains accurate for the case without hole clearance, the overestimations caused by the use of Kamtekar's shear plane [22] worsen with errors over $20 \%(1 / 0.82=1.22)$ for some models. This outcome should not be surprising since Kamtekar's shear plane coincides with the gross shear plane in this case.

Figure 7 compares the in-plane shear stress contours at the block shear limit state of Specimen T-11 between the models with and without hole clearance of $1 \mathrm{~mm}$. It can be seen that there is almost no difference between them.

It is shown in Table 2 that, for the shear-out specimens with a standard hole clearance of 3 $\mathrm{mm}$ for a $27 \mathrm{~mm}$ diameter bolt, there is an insignificant difference between Equations (3) and (4), or between the effective shear plane [9] and Kamtekar's shear plane [22]. In order to investigate the effect of hole clearances on the shear-out capacity, the combined tensile and shear fracture criteria developed by Ahmed et al. [30] was used in the present finite element analysis. The true stress-strain curve and the shear damage parameters are shown in Figure 8 and Table 5, respectively. The shear-out finite element models were validated in Table 2, and the validated models were then used to analyse bolted connections with varying hole clearances in Table 6.

Consistent with the finding for block shear specimens, the use of Kamtekar's shear plane in Equation (4) leads to an overestimation greater than $15 \%$ for the shear-out model without hole clearance, as shown in Table 6 (Model S3).

Figure 9 compares the in-plane shear stress contours at the shear-out limit state between the models with and without standard hole clearance of $3 \mathrm{~mm}$ (Models S1 and S3 in Table 6, respectively). Again it can be seen that there is insignificant difference between them.

\section{Comparisons for large hole clearance connections}

Hardash \& Bjorhovde [15] fabricated three bolted gusset specimens with a hole diameter of $17.5 \mathrm{~mm}$ for a $12.7 \mathrm{~mm}$ bolt. To the author's knowledge, these specimens had the largest hole clearance among all bolted connections tested in the literature. In fact, the hole clearance was even larger than that specified in Table J3.3M of the specification [25] for the oversize hole 
of an M20 bolt, which has a diameter of $20 \mathrm{~mm}$. For an M20 bolt, the oversize hole diameter is specified to be $24 \mathrm{~mm}$, giving a clearance of $4 \mathrm{~mm}$ "only".

Despite the very large hole clearance of the oversize specimens [15], Table 7 shows that Equation (6), which is based on the effective shear plane [9], turned out to be more accurate than Equation (5) proposed by Katemkar [22]. The use of Kamtekar's shear plane led to underestimations for the actual block shear capacities of the specimens tested by Hardash \& Bjorhovde [15].

Finite element analysis was again used to investigate the potential difference between the connections with oversize holes and similar ones without hole clearance. The true stressstrain curve is shown in Figure 10. Figure 11 compares the in-plane shear stress contours at the block shear limit state between the two models having five bolt rows, which do not show significant differences despite the very large hole clearance in one of them. As shown in Table 8, the average difference in the block shear capacities between the models with (more than) oversize holes and the corresponding ones with no hole clearance is only about $2 \%$.

In Tables 4, 6 and 8 the bolt hole diameters were kept constant in modelling the no hole clearance connections so that comparisons can be made between plates having the same geometries, for which Equation (3) or (6) gives the same capacities. However, in the interest of comparing Equations (5) and (6) against the three specimens of Hardash \& Bjorhovde [15] in the hypothetical case where the 12.7-mm bolt had no clearance, finite element models were created with bolt holes having the same diameter. The analysis results, shown in Table 9, reinforce the finding of Table 4, that the use of Kamtekar's shear plane in Equation (5) leads to significant overestimations of the block shear capacities. They also reinforce the other finding that Equation (6), based on the effective shear plane [9], is consistently accurate.

\section{Location of "shear" fracture initiation}

Photograph of a block shear specimen tested by Puthli \& Fleischer [5] well beyond the ultimate limit state, shown in Figure 12, appears to support the hypothesis of Kamtekar's shear failure plane [22], or even the gross shear plane. On the other hand, the ultimate test load of the specimen (and all other block shear specimens tested by Puthli \& Fleischer [5]) 
has been estimated accurately by Teh \& Deierlein [9] using Equation (6), which is based on the effective shear plane.

A close inspection of the severely deformed specimen shown in Figure 12 indicates that the location of fracture initiation was not the point indicated by Kamtekar's shear failure plane [22], or point A in Figure 2. The locations corresponding to points A (Kamtekar's point) and B ("gross” point) in Figure 2 are indicated in Figure 12. It can be inferred that the plate material downstream of the bolt and surrounding it had yielded and stretched substantially as the bolt bore on the hole's wall. It is therefore quite plausible that the fracture initiated close to the effective shear plane.

The preceding inference was investigated using the finite element analysis result of Model S1 in Table 6. Figure 13(a) shows the fractured state of the bolted connection model, which might superficially confirm the hypothesis of Kamtekar's shear failure plane. However, the node where a fracture initiated, denoted Node E in the figure, is actually located close to the effective shear plane, as indicated in Figure 13(b).

For the case without hole clearance (Model S3 in Table 6), the finite element analysis found that fracture would initiate on the effective shear plane, as shown in Figure 14. However, it should be noted that this finding may be incidental to the particular configuration modelled in the present work.

\section{Ultimate limit state of shear-out}

It has been explained by Clements \& Teh [29] that the block shear capacity of a bolted connection can be reached due to necking of the net tension section, well before fracture if there is a limited scope for shear strain hardening typical of high-strength steels. As the area of the net tension section reduces, the tensile resistance component decreases in the same manner as the ultimate load of a tension coupon is reached due to necking, although in the case of a block shear there may be increased contribution from shear strain hardening.

For a bolted connection undergoing the shear-out failure mode, in theory the resistance would decrease if the length of the shear failure planes reduces as the bolt bears on the hole's wall which yields. The feasibility of the ultimate shear-out capacity of a high-strength steel bolted connection being reached before fracture was investigated using a finite element model that did not incorporate fracture. For this purpose, Model S1 in Table 6 was reanalysed without 
254

255

256

257

258

259

260

261

262

263

264

265

266

267

268

269

270

271

272

273

274

275

276

277

278

279

280

281

simulating fracture. It is unknown whether the actual specimens [5] reached their ultimate test loads by fracture, but such information is not relevant to the hypothesis being examined.

The load-displacement graph obtained by the finite element analysis that did not incorporate fracture is plotted in Figure 15. The ultimate limit load is $790 \mathrm{kN}$, almost exactly the average of the ultimate test loads of Specimens 1, 2 and 3 [5] listed in Table 2, which is $792 \mathrm{kN}$.

It is therefore concluded that fracture is not necessary for the ultimate shear-out capacity of a bolted connection to be reached. Changes in the geometry of the plate material downstream of the bolt(s), in particular shortening of the shear resistance planes parallel to the loading direction, can lead to the ultimate shear-out capacity being reached. The deformed shape at the ultimate limit state of the present model is shown in Figure 16(a), which can be compared against that at the termination point of the graph plotted in Figure 15, shown in Figure 16(b).

The present finite element finding is consistent with the load-displacement graph plotted by Kim \& Yura [4] for one of their test specimens, although they appeared to attribute the attainment of the ultimate test load to "complete yielding” rather than the geometric changes of the plate material downstream of the bolt. Their graph exhibited a very gradual softening of the post-ultimate response, indicating that fracture did not take place at the ultimate limit state.

It should be noted that, for a bolted connection made of steel with very high strain hardening capability or with a highly nonlinear constitutive relationship, including stainless steel [31], fracture may be a necessary occurrence before the ultimate load is reached. In such a connection, the reduction in resistance due to geometric changes is more than offset by the increase in same due to considerable strain hardening.

\section{Conclusion}

In addition to the well-known gross and net shear planes defined by the design specifications, and the recent effective shear plane proposed by the senior author, there has been an alternative definition of shear failure planes that corresponds to the bolt diameter. The alternative definition, called Kamtekar's shear plane in this paper, coincides with the gross shear plane for bolted connections without hole clearance. 
282

283

284

285

286

287

288

289

290

291

292

293

294

295

296

297

298

299

300

301

302

303

304

305

306

307

308

309

The paper has verified the performance of the effective shear plane and Kamtekar's shear plane against independent laboratory test results and validated finite element analyses. It has been found that, for bolted connections with reduced or no hole clearance, the use of Kamtekar's shear plane leads to significant overestimations of the ultimate block shear or shear-out loads. For bolted connections with oversize hole clearance, it leads to underestimations.

In contrast, the use of the effective shear planes are consistently accurate for bolted connections with standard, oversize or no clearance bolt holes. It has been found that the shear resistance of a bolted connection is not significantly affected by the hole clearances.

The paper has demonstrated that, due to the severe deformation of the bolt hole, a superficial observation of the location of fracture initiation in a connection failing in shear-out or block shear can wrongly justify Kamtekar's shear plane, or even the gross shear plane. Careful inspection of a photograph showing such a condition has revealed that the observation is mistaken. Analyses of two finite element models having standard and no hole clearances, respectively, have found that the fracture initiates on or close to the effective shear planes for the investigated configurations.

The result of another finite element analysis ignoring fracture demonstrates that the ultimate shear-out capacity of a bolted connection can be reached before fracture if the reduction in resistance due to geometric changes is not offset by strain hardening.

\section{Acknowledgment}

This research has been conducted with the support of the Australian Government Research Training Program Scholarship for the first author, administered by the University of Wollongong. It is also supported by the Australian Research Council through the ARC Research Hub for Australian Steel Manufacturing under the Industrial Transformation Research Hubs scheme (Project ID: IH130100017).

\section{References}

[1] Teh LH, Uz, ME. Ultimate shear-out capacity of structural steel bolted connections. J Struct Eng 2015; 141 (6): 04014152. 
[2] Aalberg A, Larsen PK. Bearing strength of bolted connections in high strength steel. Proc $9^{\text {th }}$ Nordic Steel Construction Conf., Helsinki, Finland, 2001: 859-866.

[3] Aalberg A, Larsen PK. The effect of steel strength and ductility on bearing failure of bolted connections.” Proc $3^{\text {rd }}$ European Conf. Steel Structures, Coimbra, Portugal, 2002: 869-878.

[4] Kim HJ, Yura JA. The effect of ultimate-to-yield ratio on the bearing strength of bolted connections. J Construct Steel Res. 1999; 49: 255-269.

[5] Puthli R, Fleischer O. Investigations on bolted connections for high strength steel members. J Construct Steel Res. 2001; 57: 313-326.

[6] Rex CO, Easterling WS. Behavior and modelling of a bolt bearing on a single plate. J Struct Eng 2003; 129 (6): 792-800.

[7] Udagawa K, Yamada T. Failure modes and ultimate tensile strength of steel plates jointed with high strength bolts. J Struct Construct Eng AIJ 1998; 505: 115-122.

[8] Udagawa K, Yamada T. Ultimate strength and failure modes of tension channels jointed with high strength bolts. Proc $13^{\text {th }}$ World Conf Earthquake Engineering, Vancouver, BC, 2004.

[9] Teh LH, Deierlein GG. Effective shear plane model for tearout and block shear failure of bolted connections. Eng J AISC 2017; 54 (3): 181-194.

[10] Moze P, Beg D. High strength steel tension splices with one or two bolts. J Construct Steel Res. 2010; 66: 1000-1010.

[11] Moze P, Beg D. A complete study of bearing stress in single bolt connections. J Construct Steel Res. 2014; 95: 126-140.

[12] Zeynali Y, Jafari Samimi M., Mazroei, A., Asgari Mamani, Rohanimanesh, M. S. Experimental and numerical study of frictional effects on block shear fracture of steel gusset plates with bolted connections. Thin-Walled Structures 2017; 121: 8-24.

[13] Aalberg A, Larsen PK. Strength and ductility of bolted connections in normal and high strength steels, Report N-7034, Dept. of Structural Engineering, Norwegian University of Science and Technology, Trondheim, Norway, 1999.

[14] Fang C, Lam ACC, Yam MCH, Seak SK. Block shear strength of coped beams with single-sided bolted connection. J Construct Steel Res. 2013; 86: 153-166.

[15] Hardash SG, Bjorhovde R. New design criteria for gusset plates in tension. Eng J AISC 1985; 22 (2): 77-94. 
[16] Huns BBS, Grondin GY, Driver RG. Block shear behaviour of bolted gusset plates, Structural Engineering Report No. 248, Dept. of Civil and Environmental Engineering, University of Alberta, Edmonton, AB, 2002.

[17] Menzemer CC, Fei L, Srivatsan TS. Design criteria for bolted connection elements in aluminum alloy 6061. J Mech Design 1999; 121 (9): 348-358.

[18] Mullin D. Unpublished test data, Dept. of Civil and Environmental Engineering, University of Alberta, Edmonton, AB, 2002.

[19] Nast TE, Grondin GY, Cheng RJJ. Cyclic behaviour of stiffened gusset plate-brace member assemblies, Structural Engineering Report No. 229, Dept. of Civil and Environmental Engineering, University of Alberta, Edmonton, AB, 1999.

[20] Rabinovitch JS, Cheng JJR. Cyclic behaviour of steel gusset plate connections, Structural Engineering Report No. 191, Dept. of Civil and Environmental Engineering, University of Alberta, Edmonton, AB, 1993.

[21] Swanson JA, Leon RT. Bolted steel connections: Tests on T-Stub components. J Struct Eng 2000; 126 (1): 50-56.

[22] Kamtekar AG. On the bearing strength of bolts in clearance holes. J Construct Steel Res. 2012; 79: 48-55.

[23] ECS. Eurocode 3: Design of steel structures, Part 1.8: Design of joints, EN 1993-1-8, European Committee for Standardisation, 2005.

[24] Teh LH, Uz, ME. Combined bearing and shear-out capacity of structural steel bolted connections. J Struct Eng 2016; 142 (11): 04016098.

[25] ANSI/AISC 360-16. Specification for structural steel buildings, American Institute of Steel Construction, 2016.

[26] AISC. Load and Resistance Factor Design specification for structural steel buildings, American Institute of Steel Construction, 1993.

[27] Elliott MDE, Teh LH. The Whitmore tension section and block shear. J Struct Eng 2018; accepted for publication 15 August 2018.

[28] ABAQUS, ABAQUS Analysis User's Manual, Version 6.12, Dassault Systèmes, Providence RI, 2012.

[29] Clements DDA, Teh LH. Active shear planes of bolted connections failing in block shear. J Struct Eng 2013; 139 (3): 320-327.

[30] Ahmed A, Elliott MDE, Teh LH. Phenomenological tension and shear fracture criteria for structural steel bolted connections. Manuscript in preparation. 
375 [31] Salih EL, Gardner L, Nethercot DA. Bearing failure in stainless steel bolted connections. $376 \quad$ Eng Struct 2011; 33: 549-562. 


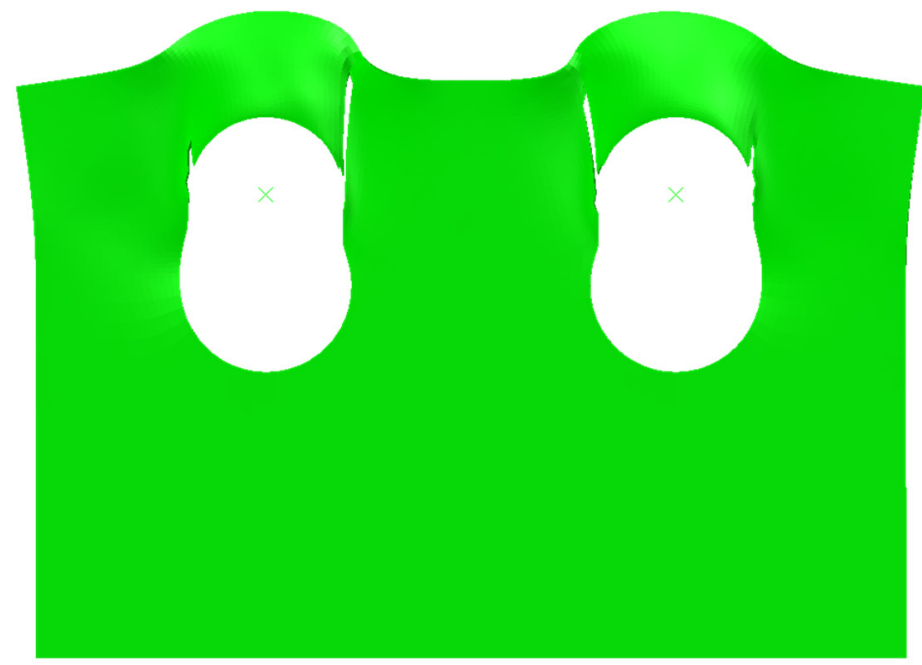

(a) Shear-out failure

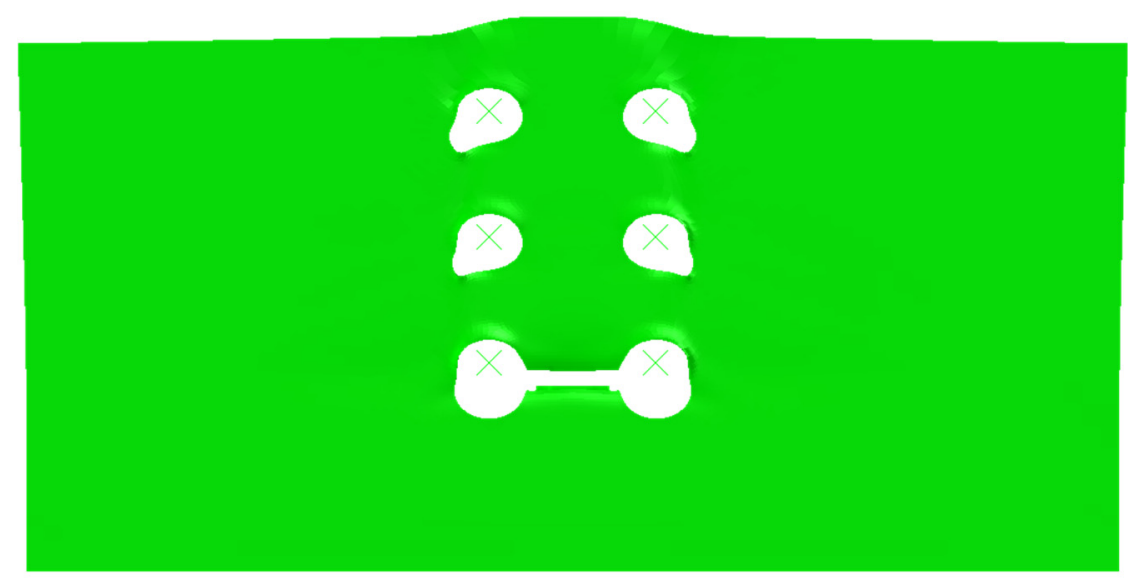

(b) Block shear failure

Figure 1 Examples of shear-out and block shear failures (post-fracture state) 


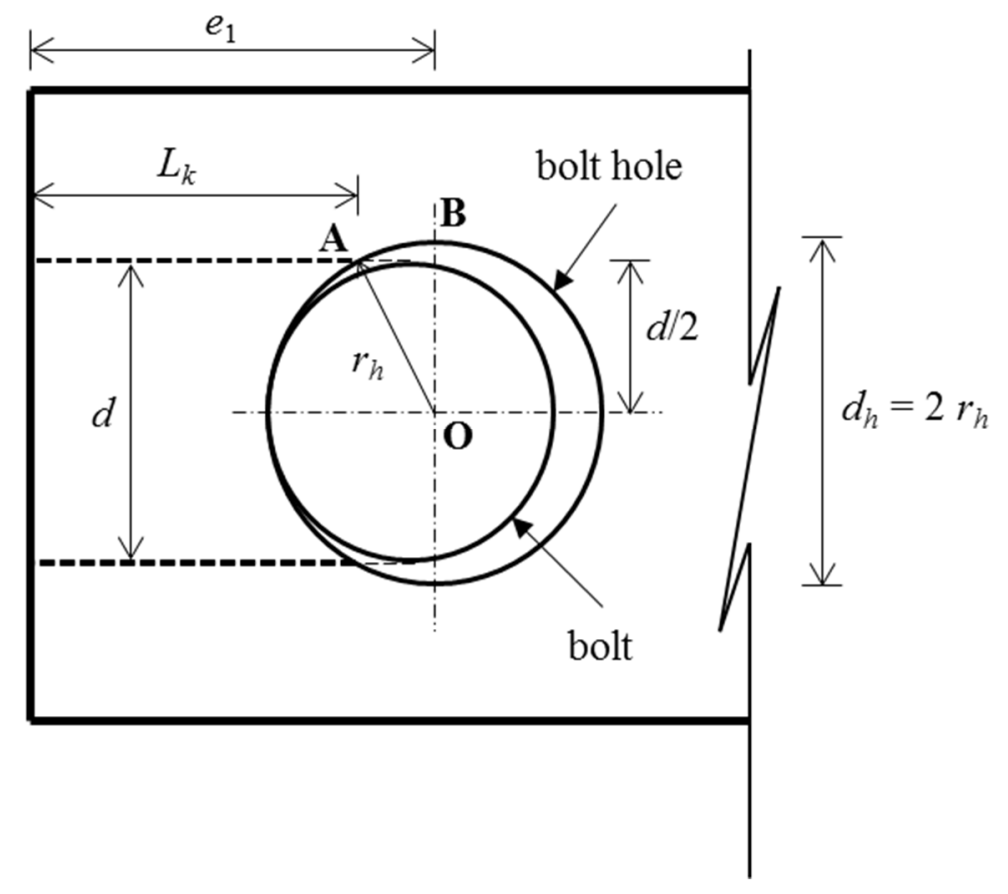

Figure 2 Kamtekar's shear failure plane [22] 


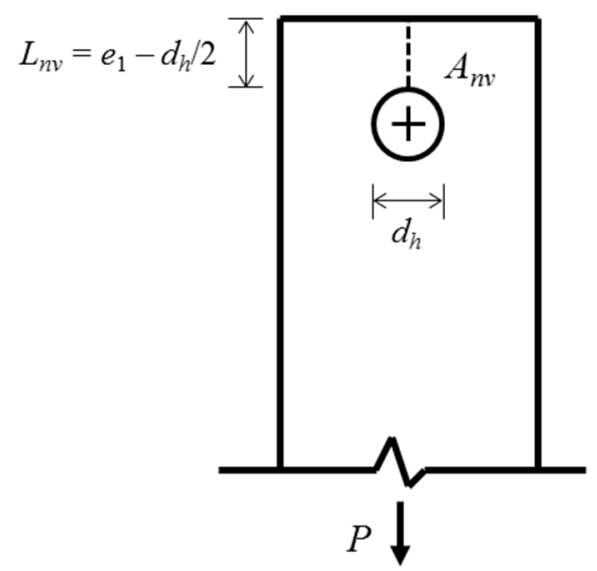

(a)

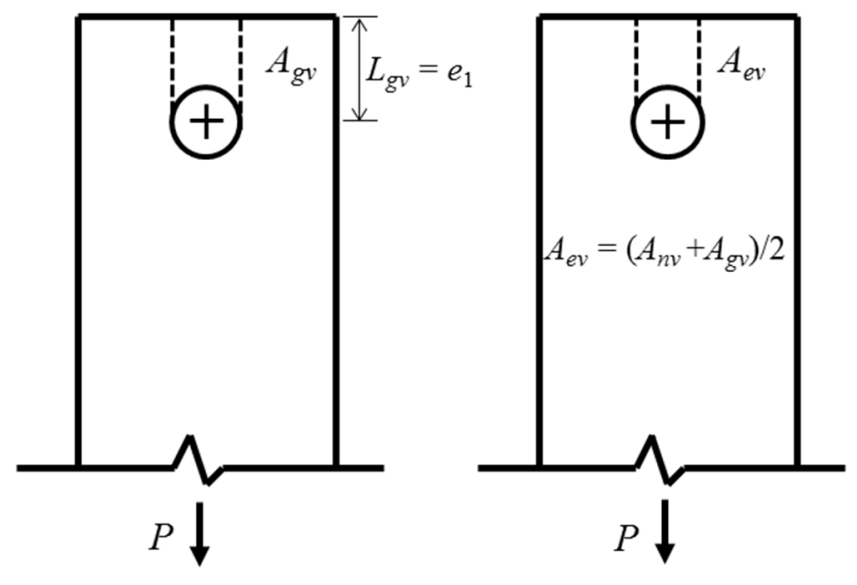

(b)

(c)

Figure 3 Alternative definitions of shear failure planes: (a) Net; (b) Gross; (c) Effective 


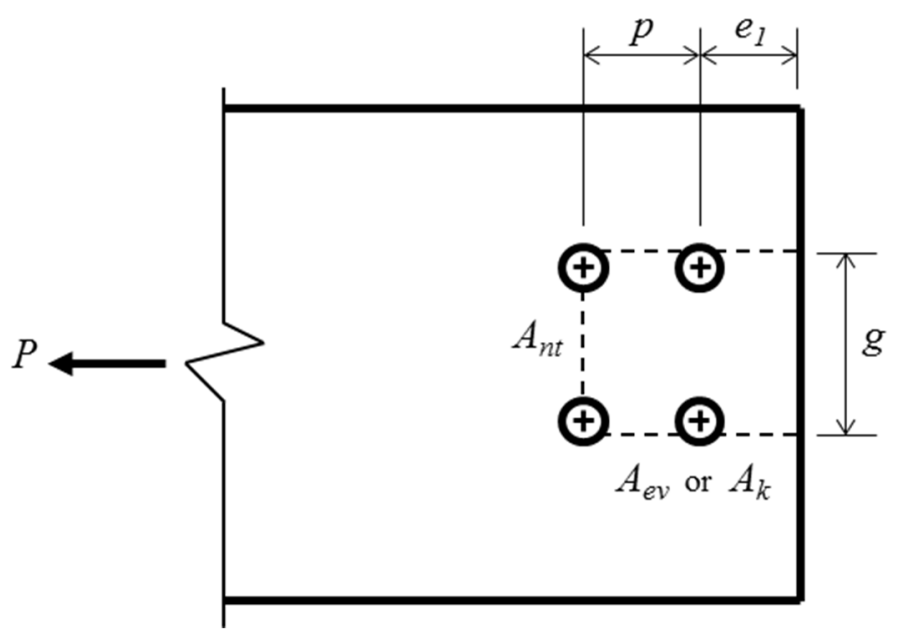

Figure 4 Block shear failure planes 


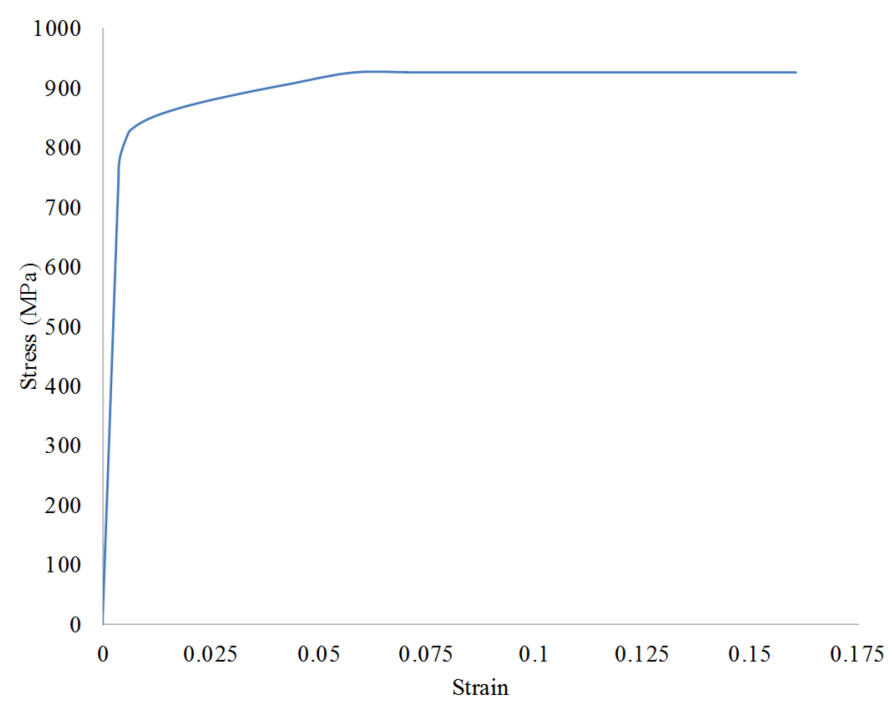

(a) $F_{\mathrm{y}}=786 \mathrm{MPa}, F_{\mathrm{u}}=822 \mathrm{MPa}$

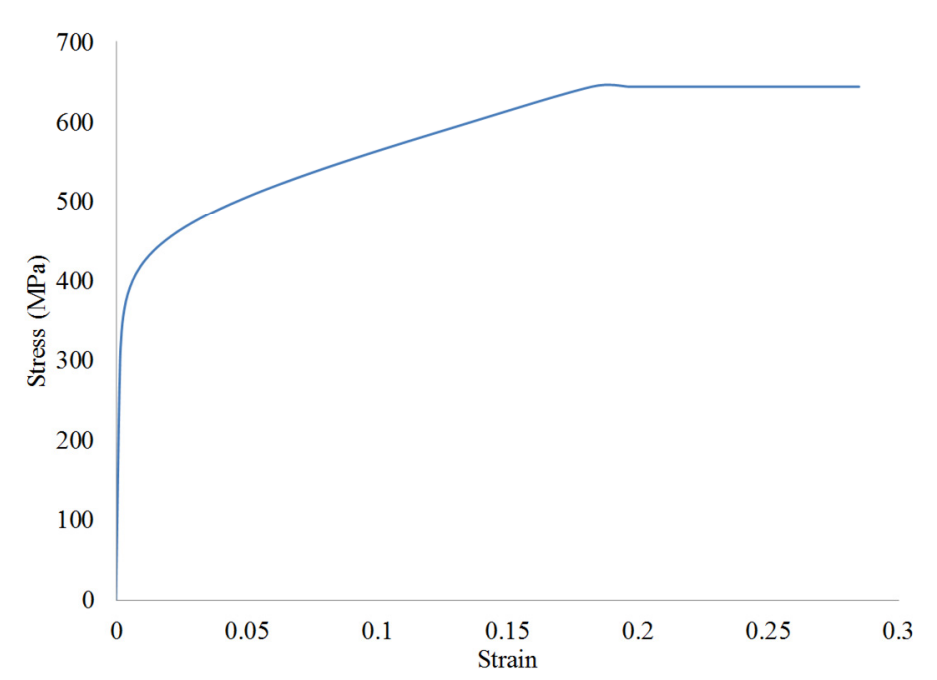

(b) $F_{\mathrm{y}}=373 \mathrm{MPa}, F_{\mathrm{u}}=537 \mathrm{MPa}$

Figure 5 True stress-strain curves: (a) Specimen T-8;

(b) Specimen T-11 


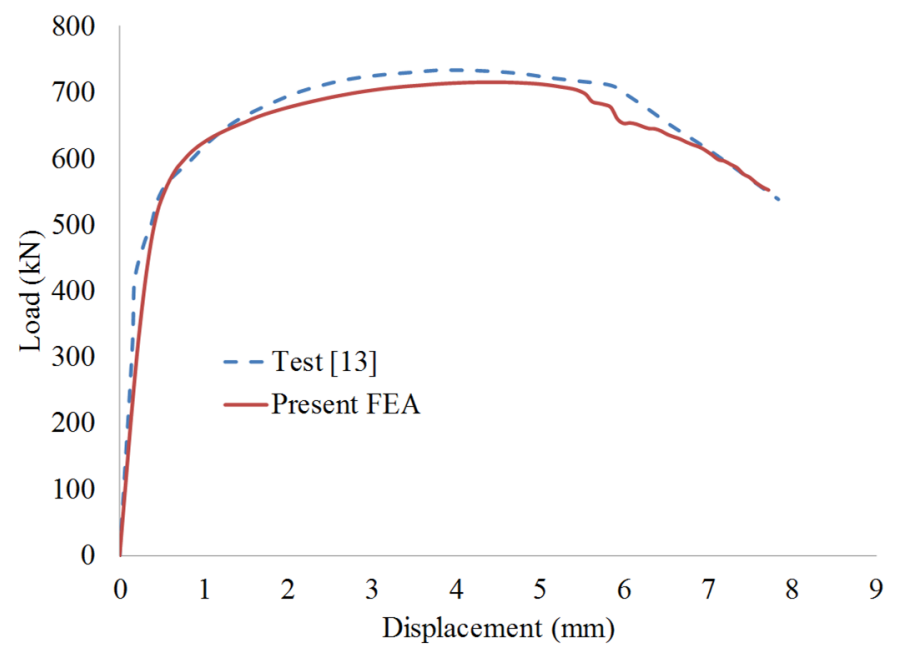

(a) Specimen T-8

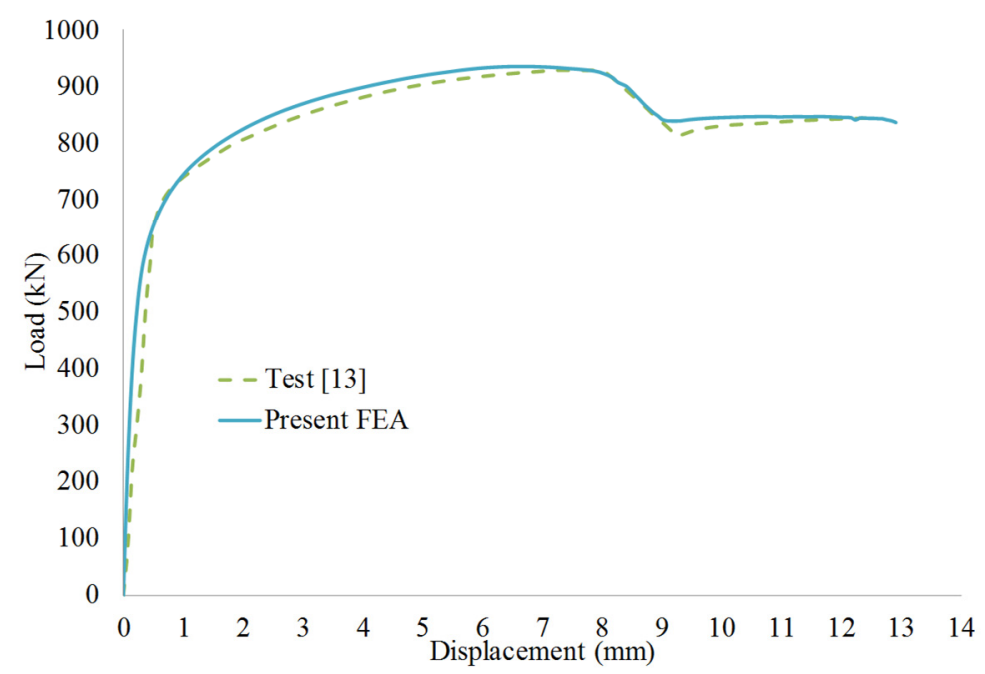

(b) Specimen T-11

Figure 6 Load-defection graphs of block shear specimens 


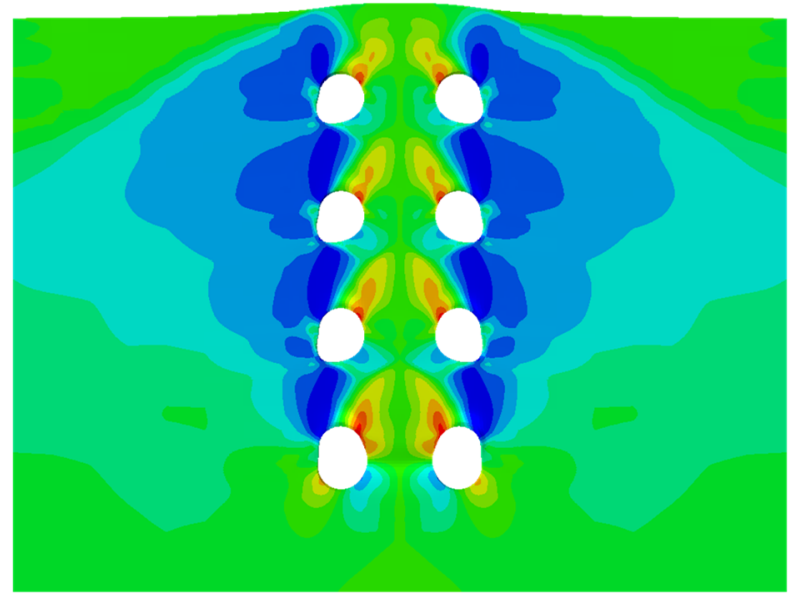

(a) With $1 \mathrm{~mm}$ hole clearance

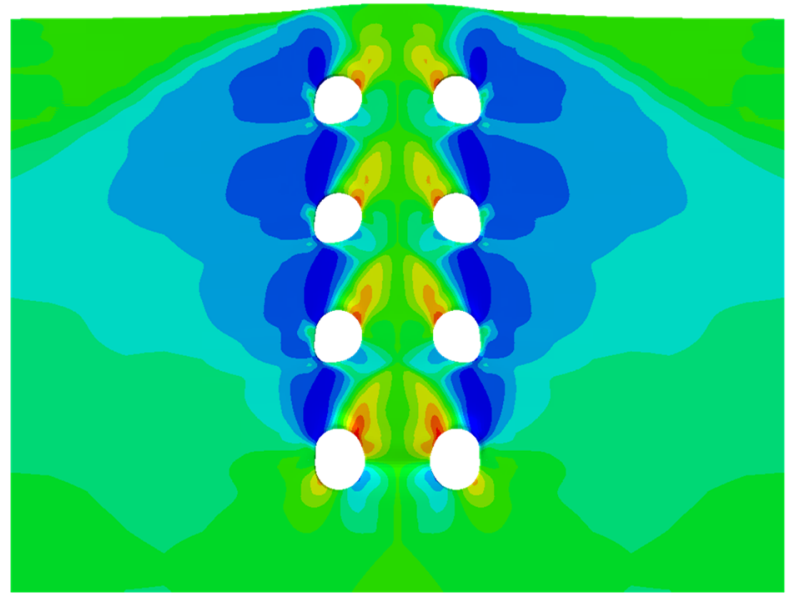

(b) Without hole clearance

Figure 7 Shear stress contours with [13] and without hole clearance 


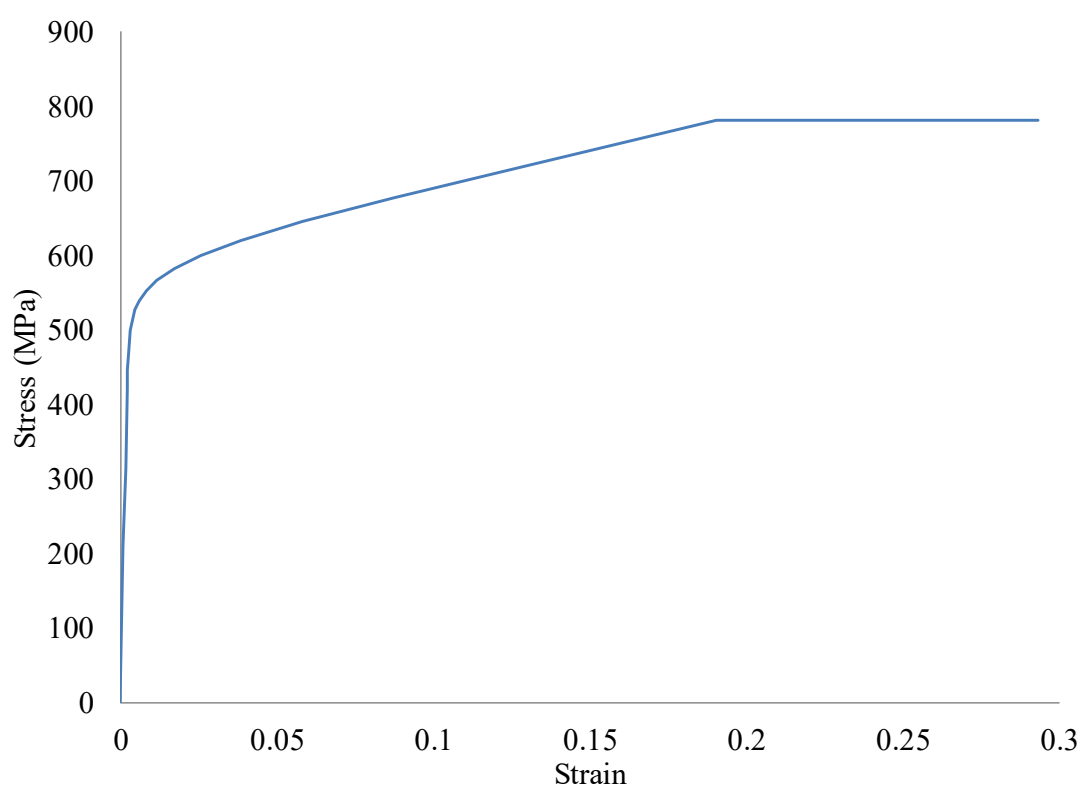

Figure 8 True stress-strain curve for shear-out specimens in Tables 2 and 6 


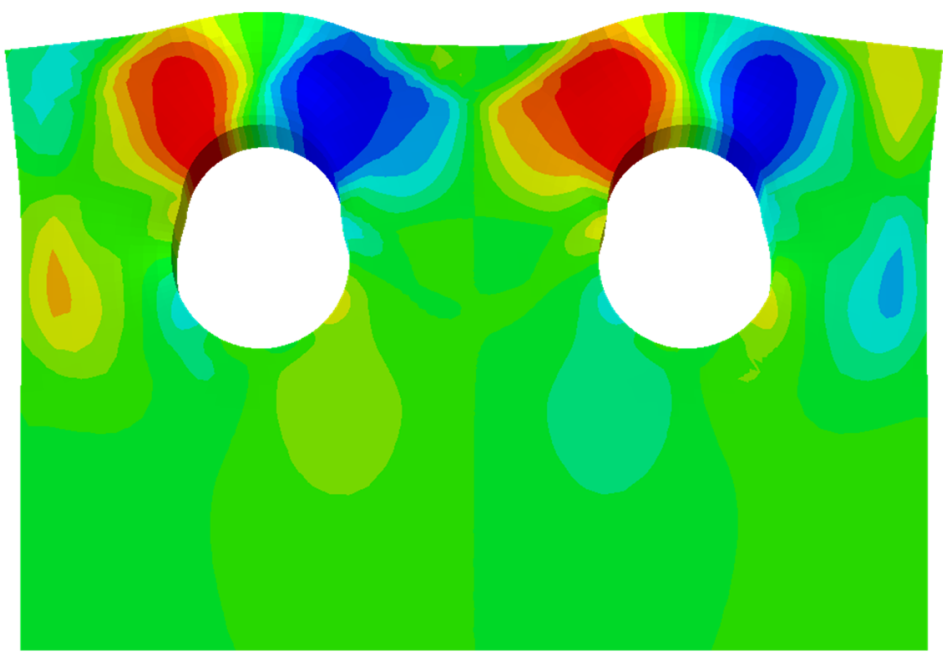

(a) With $3 \mathrm{~mm}$ hole clearance

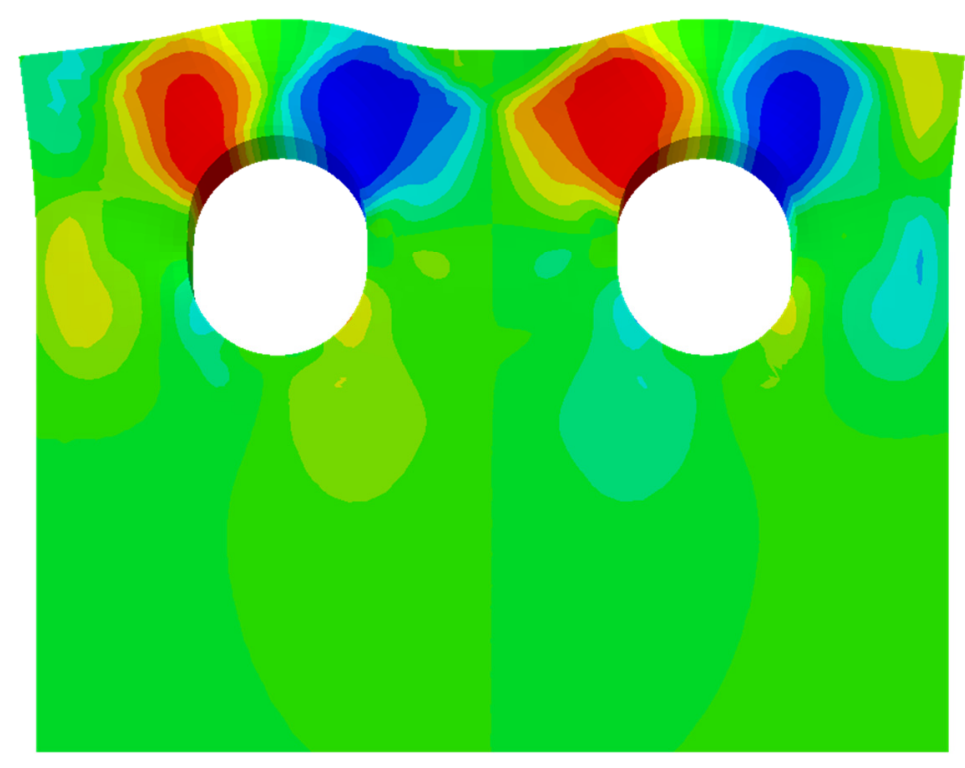

(b) Without hole clearance

Figure 9 Shear stress contours with standard (Model S1) and no hole clearance (Model S3) 


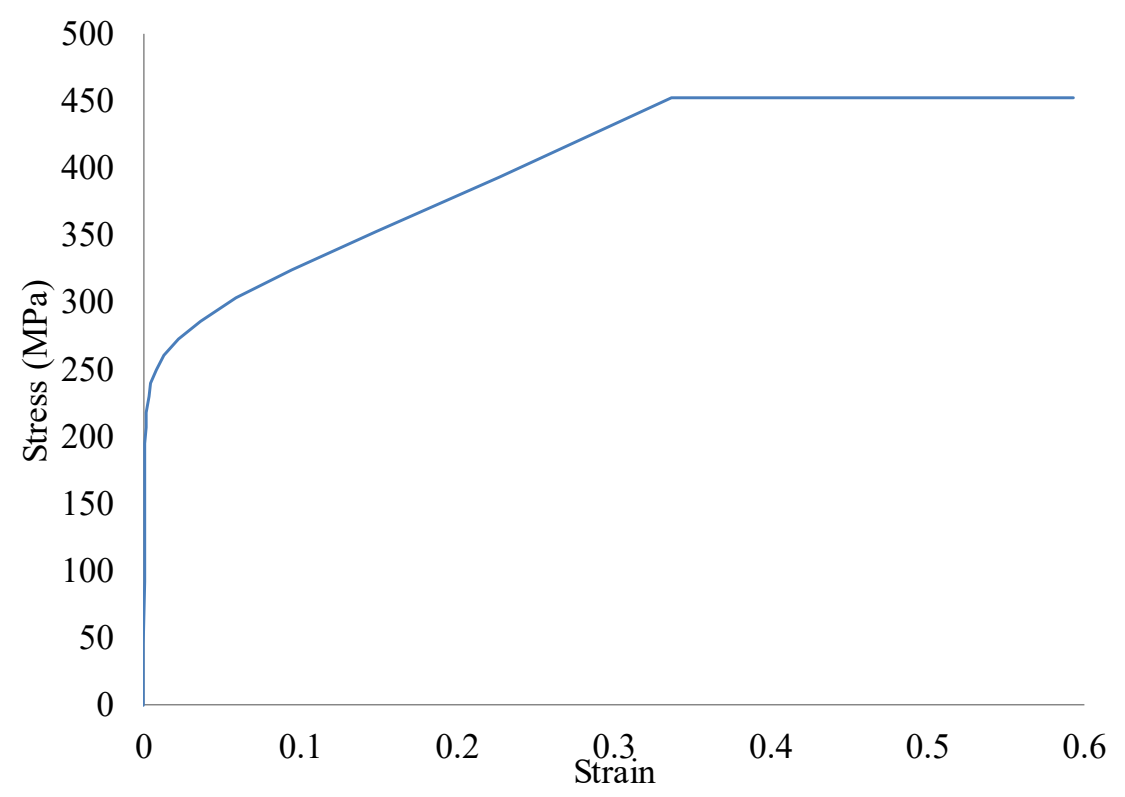

Figure 10 True stress-strain curve for oversize hole specimens in Table 8 


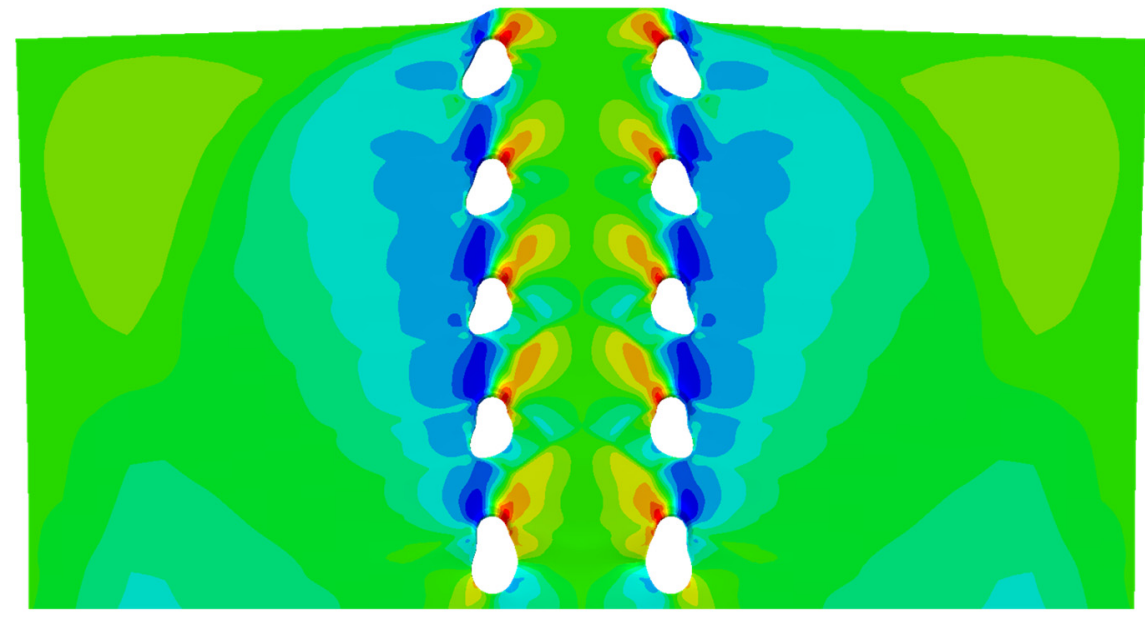

(a) With $4.75 \mathrm{~mm}$ hole clearance (more than oversize)

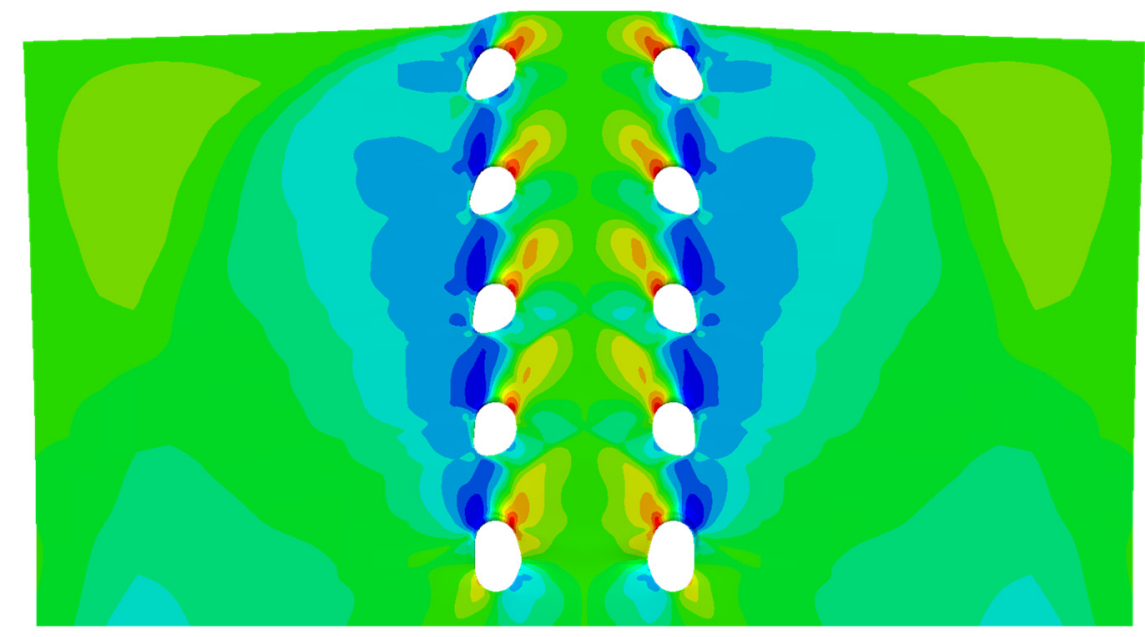

(b) Without hole clearance

Figure 11 Shear stress contours with (more than) oversize [15] and no hole clearance 


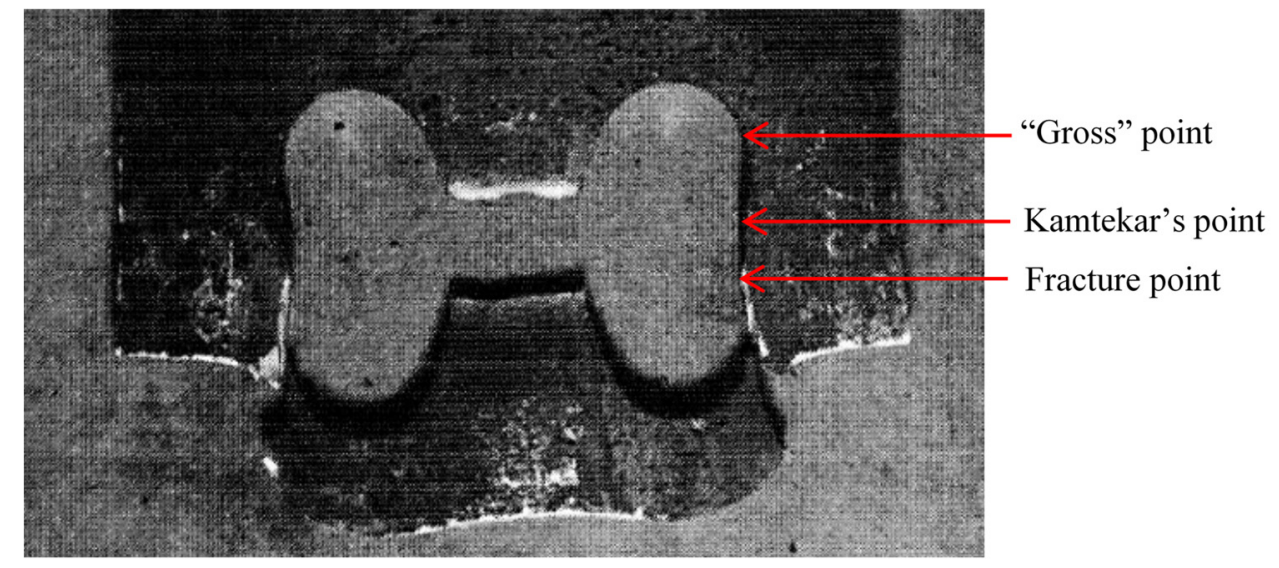

Figure 12 Block shear specimen tested by Puthli \& Fleischer [5] 


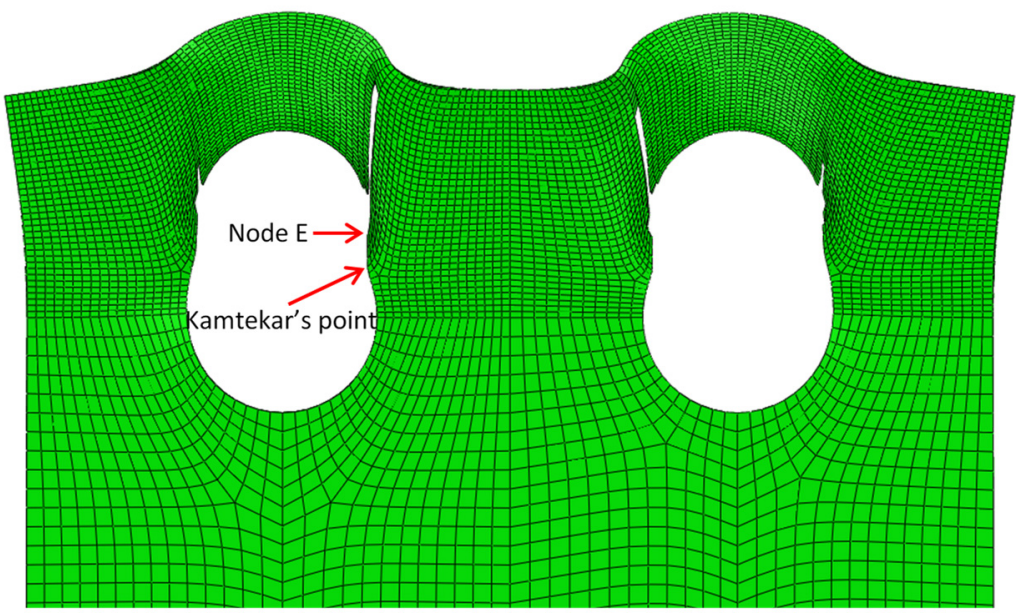

(a) Fractured state

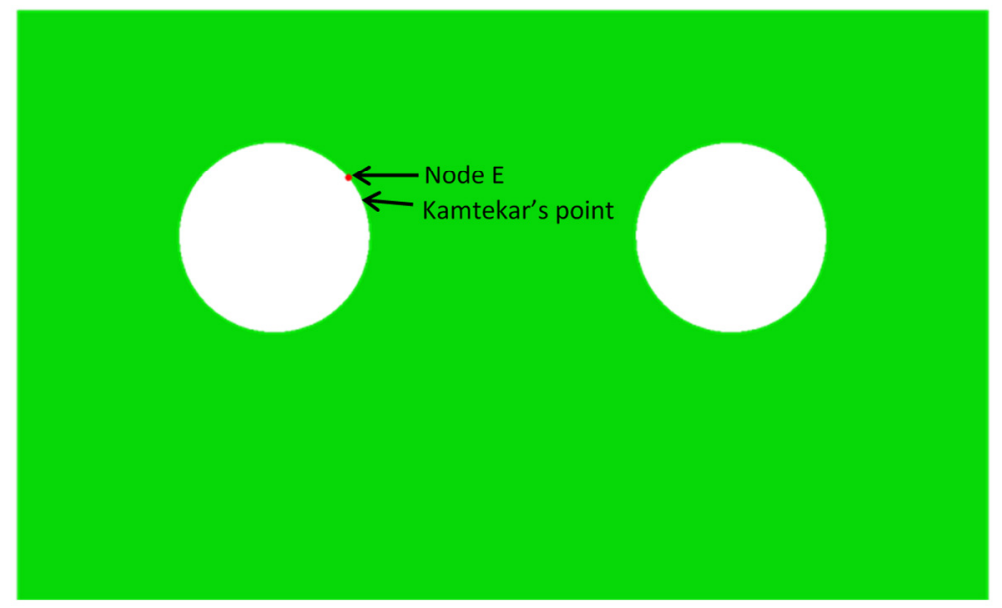

(b) Undeformed state

Figure 13 Location of fracture initiation with standard clearance (Model S1) 


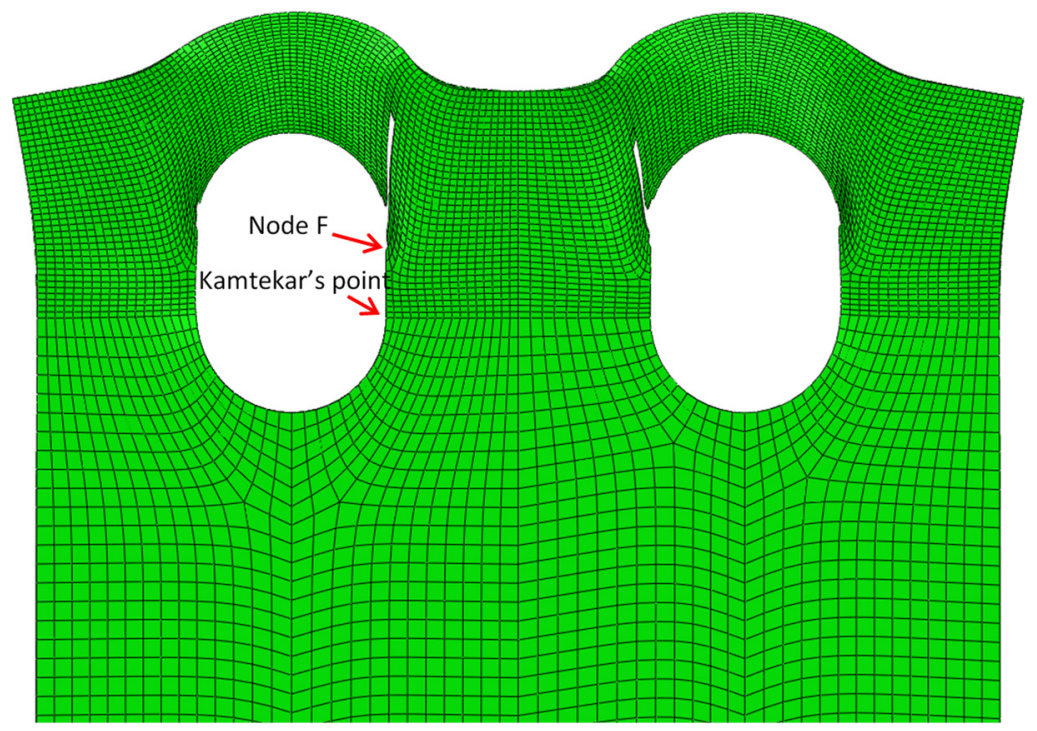

(a) Fractured state

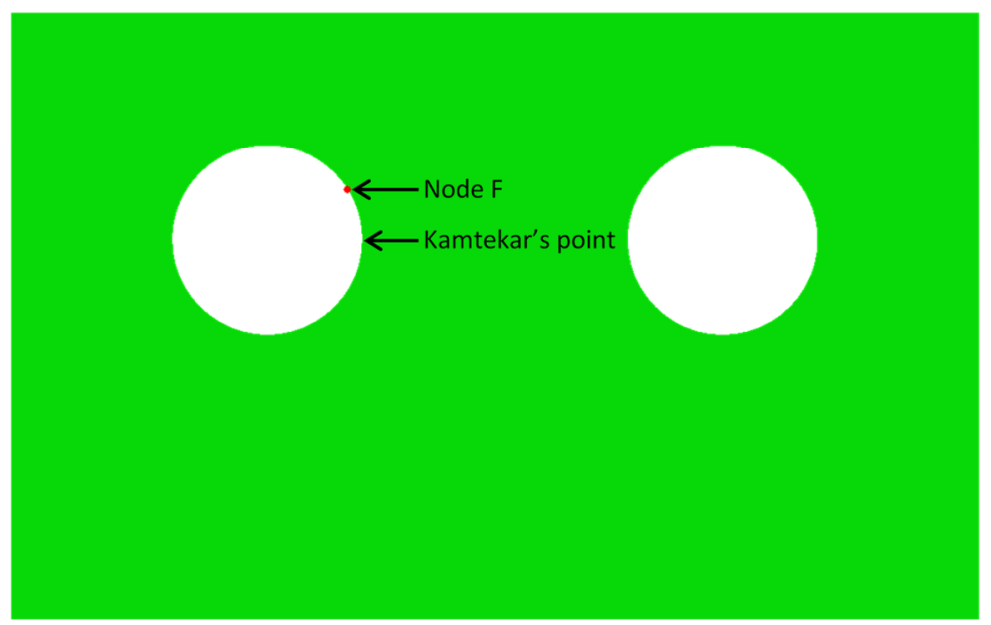

(b) Undeformed state

Figure 14 Location of fracture initiation without hole clearance (Model S3) 


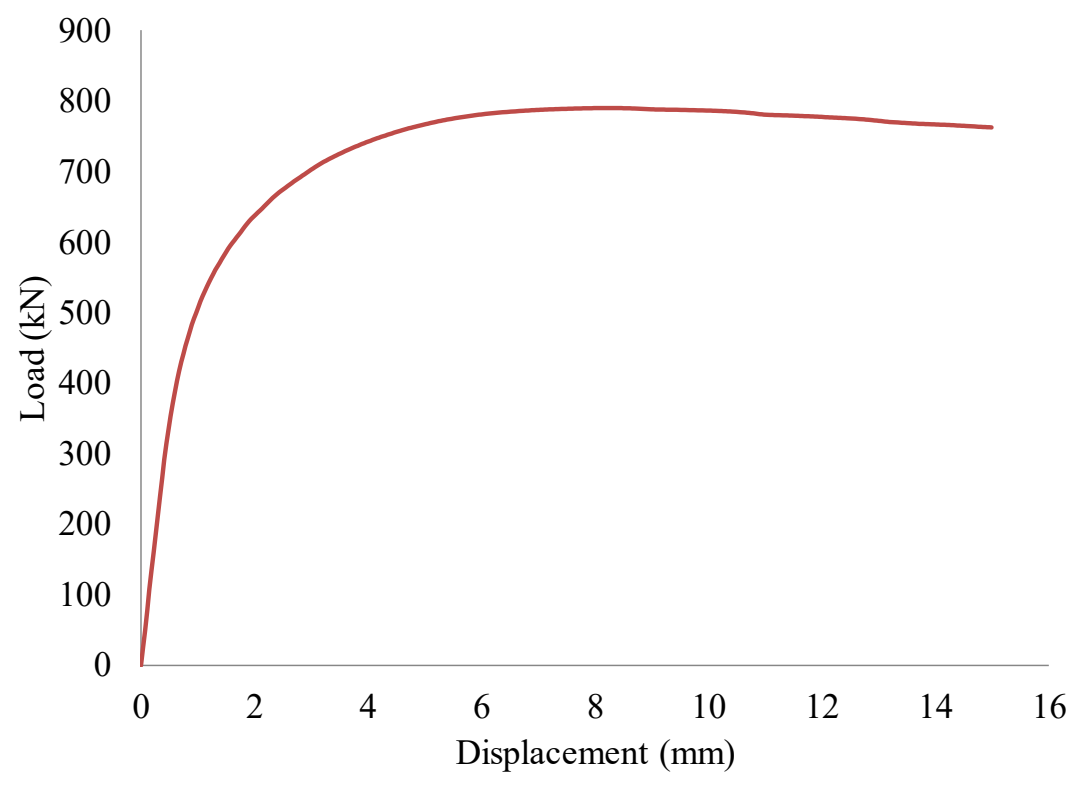

Figure 15 Load-displacement graph of Model S1 without incorporating fracture 


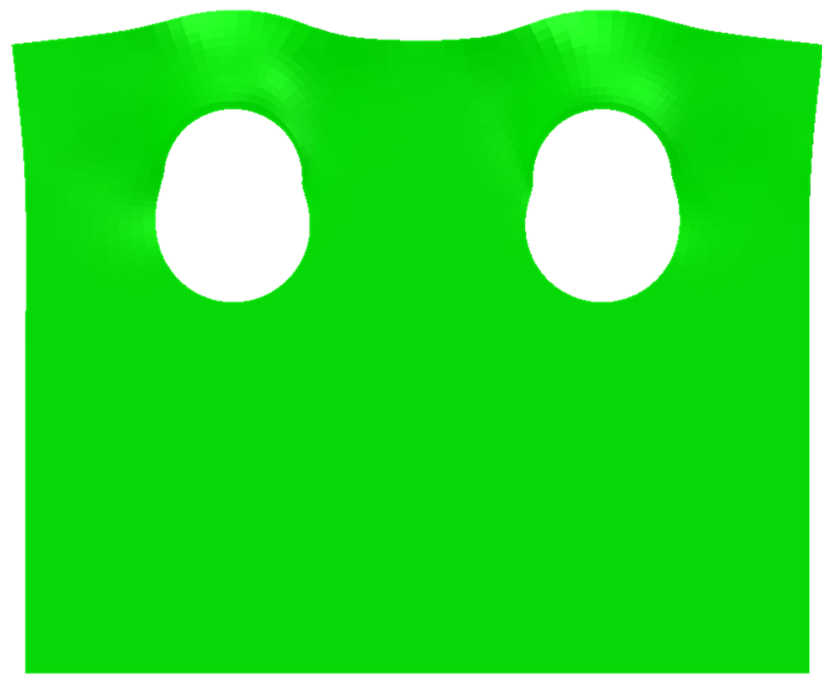

(a) At the ultimate limit state

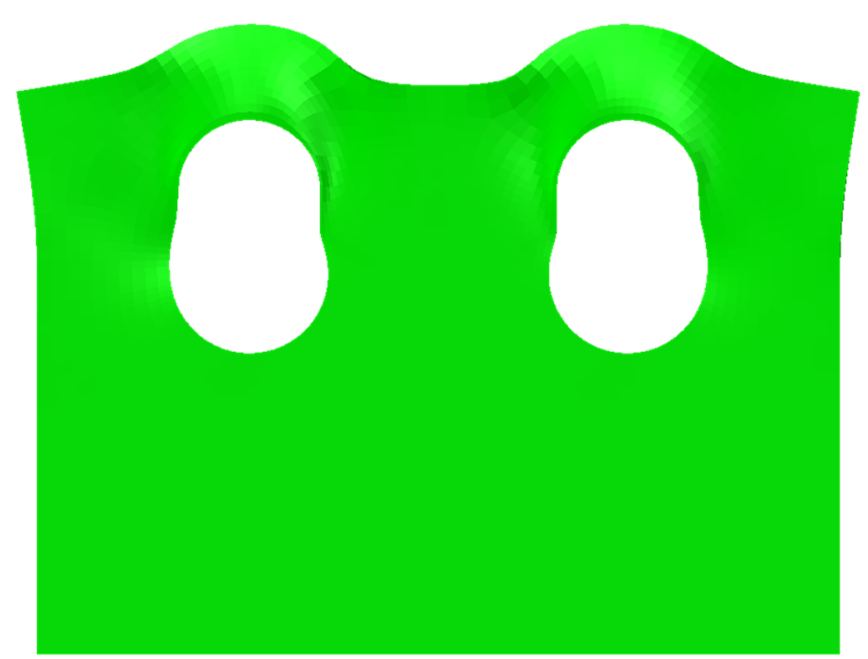

(b) At the termination point

Figure 16 Deformed shapes in the shear-out failure mode without fracture 
Table 1. Comparisons for block shear specimens of Aalberg \& Larsen [13]

\begin{tabular}{|c|c|c|c|c|c|c|c|c|c|c|c|c|}
\hline \multirow{2}{*}{ Spec } & \multirow{2}{*}{$\begin{array}{c}d_{h} \\
(\mathbf{m m})\end{array}$} & \multirow{2}{*}{$\begin{array}{c}d \\
(\mathrm{~mm})\end{array}$} & \multirow{2}{*}{$\begin{array}{c}e_{1} \\
(\mathbf{m m})\end{array}$} & \multirow{2}{*}{$\begin{array}{c}g \\
(\mathrm{~mm})\end{array}$} & \multirow{2}{*}{$\begin{array}{c}p \\
(\mathrm{~mm})\end{array}$} & \multirow{2}{*}{$\begin{array}{c}t \\
(\mathrm{~mm})\end{array}$} & \multirow{2}{*}{$n_{\mathbf{r}}$} & \multirow{2}{*}{$\begin{array}{c}F_{\mathbf{u}} \\
(\mathbf{M P a})\end{array}$} & \multirow{2}{*}{$\begin{array}{c}P_{t} \\
(\mathbf{k N})\end{array}$} & \multicolumn{3}{|c|}{$\boldsymbol{P}_{\mathrm{t}} / \boldsymbol{P}_{\mathrm{bs}}$} \\
\hline & & & & & & & & & & Eqn (5) & Eqn (6) & FEA \\
\hline $\mathrm{T}-7$ & 19 & 18 & 38 & 47.5 & 47.5 & 8.4 & 2 & 537 & 551 & 1.02 & 1.07 & 1.05 \\
\hline $\mathrm{T}-8$ & & & & & & 7.7 & & 822 & 730 & 0.96 & 1.01 & 0.99 \\
\hline T-9 & & & & & & 8.4 & 3 & 537 & 751 & 0.98 & 1.04 & 1.02 \\
\hline *T-15 & & & & & & & & & 710 & 0.93 & 0.99 & 1.03 \\
\hline $\mathrm{T}-10$ & & & & & & 7.7 & & 822 & 994 & 0.92 & 0.98 & 0.96 \\
\hline *T-16 & & & & & & & & & 961 & 0.89 & 0.95 & 1.00 \\
\hline $\mathrm{T}-11$ & & & & & & 8.4 & 4 & 537 & 925 & 0.93 & 1.00 & 0.98 \\
\hline $\mathrm{T}-12$ & & & & & & 7.7 & & 822 & 1229 & 0.88 & 0.94 & 0.92 \\
\hline & & & & & & & & & Mean & 0.94 & 1.00 & 0.99 \\
\hline & & & & & & & & & $\mathrm{COV}$ & 0.045 & 0.041 & 0.038 \\
\hline
\end{tabular}

*These I-section specimens had their flanges removed.

Table 2. Comparisons for shear-out specimens of Puthli \& Fleischer [5] (a row of 2 bolts)

\begin{tabular}{|c|c|c|c|c|c|c|c|c|c|c|}
\hline \multirow{2}{*}{ Spec } & \multirow{2}{*}{$\begin{array}{c}d_{\mathrm{h}} \\
(\mathrm{mm})\end{array}$} & \multirow{2}{*}{$\begin{array}{c}d \\
(\mathrm{~mm})\end{array}$} & \multirow{2}{*}{$\begin{array}{c}e_{1} \\
(\mathbf{m m})\end{array}$} & \multirow{2}{*}{$\begin{array}{c}g \\
(\mathbf{m m})\end{array}$} & \multirow{2}{*}{$\begin{array}{c}t \\
(\mathrm{~mm})\end{array}$} & \multirow{2}{*}{$\begin{array}{c}F_{\mathrm{u}} \\
(\mathrm{MPa})\end{array}$} & \multirow{2}{*}{$\begin{array}{c}P_{t} \\
(k N)\end{array}$} & \multicolumn{3}{|c|}{$\boldsymbol{P}_{\mathrm{t}} / \boldsymbol{P}_{\text {so }}$} \\
\hline & & & & & & & & Eqn (4) & Eqn (3) & FEA \\
\hline 1 & 30 & 27 & 36 & 72 & 17.5 & 645 & 817 & 1.02 & 1.06 & 1.04 \\
\hline 2 & & & & & & & 774 & 0.97 & 1.00 & 0.99 \\
\hline 3 & & & & & & & 785 & 0.98 & 1.02 & 1.00 \\
\hline 4 & & & & 81 & & & 755 & 0.95 & 0.98 & 0.96 \\
\hline 5 & & & & & & & 772 & 0.97 & 1.00 & 0.99 \\
\hline 6 & & & & & & & 771 & 0.97 & 1.00 & 0.99 \\
\hline 7 & & & & 90 & & & 811 & 1.02 & 1.05 & 1.04 \\
\hline 8 & & & & & & & 801 & 1.00 & 1.04 & 1.02 \\
\hline 9 & & & & & & & 813 & 1.02 & 1.05 & 1.04 \\
\hline & & & & & & & Mean & 0.99 & 1.02 & 1.01 \\
\hline
\end{tabular}


Table 3. Ductile damage parameters for block shear specimens

\begin{tabular}{ccc}
\hline Steel Grade & Stress Triaxiality & Fracture Strain \\
\hline & 0 & 2 \\
& 0.20 & 1.25 \\
Weldox 700 & 0.45 & 0.5 \\
$F_{\mathrm{y}}=786 \mathrm{MPa}$ & 0.50 & 0.15 \\
$F_{\mathrm{u}}=822 \mathrm{MPa}$ & 0.57 & 0.5 \\
& 0.68 & 1 \\
& 1 & 2 \\
\hline & 0 & 2 \\
& 0.20 & 1.25 \\
& 0.45 & 0.75 \\
$F_{\mathrm{y}}=373 \mathrm{MPa}$ & 0.50 & 0.30 \\
$F_{\mathrm{u}}=537 \mathrm{MPa}$ & 0.57 & 0.75 \\
& 0.68 & 1 \\
& 1 & 2 \\
\hline
\end{tabular}

Table 4. Comparisons for block shear connections without hole clearance

\begin{tabular}{|c|c|c|c|c|c|c|c|c|c|c|c|c|}
\hline \multirow{2}{*}{ Model } & \multirow{2}{*}{$\begin{array}{c}d_{\mathrm{h}} \\
(\mathrm{mm})\end{array}$} & \multirow{2}{*}{$\begin{array}{c}d \\
(\mathrm{~mm})\end{array}$} & \multirow{2}{*}{$\begin{array}{c}e_{1} \\
(\mathrm{~mm})\end{array}$} & \multirow{2}{*}{$\underset{(\mathrm{mm})}{g}$} & \multirow{2}{*}{$\underset{(\mathbf{m m})}{p}$} & \multirow{2}{*}{$\begin{array}{c}t \\
(\mathrm{~mm})\end{array}$} & \multirow{2}{*}{$n_{\mathrm{r}}$} & \multirow{2}{*}{$\begin{array}{c}F_{\mathbf{y}} \\
(\mathrm{MPa})\end{array}$} & \multirow{2}{*}{$\begin{array}{c}F_{\mathbf{u}} \\
(\mathrm{MPa})\end{array}$} & \multirow{2}{*}{$\begin{array}{c}P_{\mathrm{u}} \\
(\mathrm{kN})\end{array}$} & \multicolumn{2}{|c|}{$\boldsymbol{P}_{\mathrm{u}} / \boldsymbol{P}_{\mathrm{bs}}$} \\
\hline & & & & & & & & & & & Eqn (5) & Eqn (6) \\
\hline $\mathrm{T}-7 \mathrm{M}$ & 19 & 19 & 38 & 47.5 & 47.5 & 8.4 & 2 & 373 & 537 & 535 & 0.90 & 1.04 \\
\hline $\mathrm{T}-8 \mathrm{M}$ & & & & & & 7.7 & & 786 & 822 & 753 & 0.90 & 1.04 \\
\hline $\mathrm{T}-9 \mathrm{M}$ & & & & & & 8.4 & 3 & 373 & 537 & 740 & 0.87 & 1.03 \\
\hline *T-15M & & & & & & & & & & 695 & 0.82 & 0.96 \\
\hline $\mathrm{T}-10 \mathrm{M}$ & & & & & & 7.7 & & 786 & 822 & 1054 & 0.88 & 1.04 \\
\hline${ }^{*} \mathrm{~T}-16 \mathrm{M}$ & & & & & & & & & & 974 & 0.82 & 0.96 \\
\hline $\mathrm{T}-11 \mathrm{M}$ & & & & & & 8.4 & 4 & 373 & 537 & 953 & 0.86 & 1.03 \\
\hline $\mathrm{T}-12 \mathrm{M}$ & & & & & & 7.7 & & 786 & 822 & 1364 & 0.88 & 1.05 \\
\hline & & & & & & & & & & Mean & 0.87 & 1.02 \\
\hline & & & & & & & & & & COV & 0.037 & 0.032 \\
\hline
\end{tabular}

*These I-section specimens had their flanges removed. 
Table 5. Shear damage parameters for shear-out specimens

\begin{tabular}{cc}
\hline Shear Stress Ratio & Fracture Strain \\
\hline 1.732 & 1 \\
1.743 & 1.02 \\
1.8 & 3 \\
\hline
\end{tabular}

Table 6. Comparisons for shear-out connections with varying hole clearances (a row of 2 bolts)

\begin{tabular}{|c|c|c|c|c|c|c|c|c|c|c|}
\hline \multirow[b]{2}{*}{ Model } & \multirow{2}{*}{$\begin{array}{c}d_{h} \\
(\mathbf{m m})\end{array}$} & \multirow{2}{*}{$\begin{array}{c}d \\
(\mathrm{~mm})\end{array}$} & \multirow{2}{*}{$\begin{array}{c}e_{1} \\
(\mathbf{m m})\end{array}$} & \multirow{2}{*}{$\begin{array}{c}g \\
(\mathrm{~mm})\end{array}$} & \multirow{2}{*}{$\begin{array}{c}t \\
(\mathrm{~mm})\end{array}$} & \multirow{2}{*}{$\begin{array}{c}F_{\mathrm{y}} \\
(\mathrm{MPa})\end{array}$} & \multirow{2}{*}{$\begin{array}{c}F_{\mathbf{u}} \\
(\mathrm{MPa})\end{array}$} & \multirow{2}{*}{$\begin{array}{c}P_{\mathbf{u}} \\
(\mathbf{k N})\end{array}$} & \multicolumn{2}{|c|}{$\boldsymbol{P}_{\mathrm{u}} / \boldsymbol{P}_{\text {so }}$} \\
\hline & & & & & & & & & $\begin{array}{c}\text { Eqn } \\
\text { (4) }\end{array}$ & $\begin{array}{c}\text { Eqn } \\
\text { (3) }\end{array}$ \\
\hline S1 & 30 & 27 & 36 & 72 & 17.5 & 524 & 645 & 783 & 0.98 & 1.01 \\
\hline $\mathrm{S} 2$ & & 29 & & & & & & 810 & 0.93 & 1.05 \\
\hline \multirow[t]{3}{*}{ S3 } & & 30 & & & & & & 824 & 0.85 & 1.07 \\
\hline & & & & & & & & Mean & 0.92 & 1.04 \\
\hline & & & & & & & & $\mathrm{COV}$ & 0.075 & 0.026 \\
\hline
\end{tabular}

Table 7. Comparisons for oversize hole specimens of Hardash \& Bjorhovde [15]

\begin{tabular}{|c|c|c|c|c|c|c|c|c|c|c|c|}
\hline \multirow{2}{*}{ Spec } & \multirow{2}{*}{$\begin{array}{c}d_{\mathrm{h}} \\
(\mathrm{mm})\end{array}$} & \multirow{2}{*}{$\begin{array}{c}d \\
(\mathrm{~mm})\end{array}$} & \multirow{2}{*}{$\begin{array}{c}e_{1} \\
(\mathbf{m m})\end{array}$} & \multirow{2}{*}{$\begin{array}{c}g \\
(\mathrm{~mm})\end{array}$} & \multirow{2}{*}{$\begin{array}{c}p \\
(\mathrm{~mm})\end{array}$} & \multirow{2}{*}{$\begin{array}{c}t \\
(\mathrm{~mm})\end{array}$} & \multirow{2}{*}{$n_{r}$} & \multirow{2}{*}{$\begin{array}{c}F_{\mathrm{u}} \\
(\mathrm{MPa})\end{array}$} & \multirow{2}{*}{$\begin{array}{c}P_{t} \\
(\mathbf{k N})\end{array}$} & \multicolumn{2}{|c|}{$\boldsymbol{P}_{\mathrm{t}} / \boldsymbol{P}_{\mathrm{bs}}$} \\
\hline & & & & & & & & & & Eqn (5) & Eqn (6) \\
\hline 16 & 17.5 & 12.7 & 38.1 & 50.8 & 50.8 & 6.0 & 4 & 323 & 444 & 1.08 & 1.01 \\
\hline 20 & & & & 76.2 & & & & & 532 & 1.15 & 1.09 \\
\hline \multirow[t]{3}{*}{26} & & & 25.4 & & & & 5 & & 584 & 1.12 & 1.05 \\
\hline & & & & & & & & & Mean & 1.12 & 1.05 \\
\hline & & & & & & & & & $\mathrm{COV}$ & 0.034 & 0.037 \\
\hline
\end{tabular}

Table 8. FEA comparisons between oversize and no hole clearance connections

\begin{tabular}{|c|c|c|c|c|c|c|c|c|c|c|c|}
\hline \multirow{2}{*}{ Model } & \multirow{2}{*}{$\begin{array}{c}d_{\mathrm{h}} \\
(\mathrm{mm})\end{array}$} & \multirow{2}{*}{$\begin{array}{c}e_{1} \\
(\mathbf{m m})\end{array}$} & \multirow{2}{*}{$\begin{array}{c}g \\
(\mathrm{~mm})\end{array}$} & \multirow{2}{*}{$\underset{(\mathbf{m m})}{p}$} & \multirow{2}{*}{$\begin{array}{c}t \\
(\mathrm{~mm})\end{array}$} & \multirow{2}{*}{$n_{\mathrm{r}}$} & \multirow{2}{*}{$\begin{array}{c}F_{\mathbf{y}} \\
(\mathrm{MPa})\end{array}$} & \multirow{2}{*}{$\begin{array}{c}F_{\mathbf{u}} \\
(\mathrm{MPa})\end{array}$} & \multicolumn{3}{|c|}{$P_{\mathrm{u}}(\mathbf{k N})$} \\
\hline & & & & & & & & & Oversize & No clearance & \%Diff \\
\hline $16 \mathrm{M}$ & 17.5 & 38.1 & 50.8 & 50.8 & 6.0 & 4 & 229 & 323 & 438 & 446 & 1.7 \\
\hline $20 \mathrm{M}$ & & & 76.2 & & & & & & 491 & 502 & 2.3 \\
\hline \multirow[t]{2}{*}{$26 \mathrm{M}$} & & 25.4 & & & & 5 & & & 540 & 554 & 2.6 \\
\hline & & & & & & & & & & Mean & 2.2 \\
\hline
\end{tabular}


Table 9. Comparisons for no hole clearance specimens of Hardash \& Bjorhovde [15]

\begin{tabular}{|c|c|c|c|c|c|c|c|c|c|c|}
\hline \multirow{2}{*}{ Model } & \multirow{2}{*}{$\begin{array}{c}d_{\mathrm{h}} \\
(\mathrm{mm})\end{array}$} & \multirow{2}{*}{$\begin{array}{c}e_{1} \\
(\mathrm{~mm})\end{array}$} & \multirow{2}{*}{$\begin{array}{c}g \\
(\mathbf{m m})\end{array}$} & \multirow{2}{*}{$\begin{array}{c}p \\
(\mathbf{m m})\end{array}$} & \multirow{2}{*}{$\begin{array}{c}t \\
(\mathrm{~mm})\end{array}$} & \multirow{2}{*}{$n_{r}$} & \multirow{2}{*}{$\begin{array}{c}F_{\mathrm{u}} \\
(\mathrm{MPa})\end{array}$} & \multirow{2}{*}{$\begin{array}{c}P_{\mathbf{u}} \\
(\mathbf{k N})\end{array}$} & \multicolumn{2}{|c|}{$\boldsymbol{P}_{\mathrm{t}} / \boldsymbol{P}_{\mathrm{bs}}$} \\
\hline & & & & & & & & & Eqn (5) & Eqn (6) \\
\hline $16 \mathrm{H}$ & 12.7 & 38.1 & 50.8 & 50.8 & 6.0 & 4 & 323 & 475 & 0.92 & 1.02 \\
\hline $20 \mathrm{H}$ & & & 76.2 & & & & & 522 & 0.92 & 1.01 \\
\hline $26 \mathrm{H}$ & & 25.4 & & & & 5 & & 580 & 0.88 & 0.98 \\
\hline & & & & & & & & Mean & 0.91 & 1.00 \\
\hline & & & & & & & & $\mathrm{COV}$ & 0.018 & 0.016 \\
\hline
\end{tabular}

